\title{
RADIOCARBON AMS DATING OF POLLEN EXTRACTED FROM PEAT SAMPLES
}

\author{
T. A. BROWN ${ }^{1,2}$, G. W. FARWELL $L^{1}$, P. M. GROOTES ${ }^{1,3}$ and F. H. SCHMIDT $T^{1,4}$
}

ABSTRACT. We present ${ }^{14} \mathrm{C}$ AMS measurements and discuss the extraction procedure used on pollen extracted from peat samples. Microscopic examination of the extracts shows that the procedure is sufficient to remove most non-pollen materials and results in an extract that is composed predominantly of pollen. The ${ }^{14} \mathrm{C}$ dates that we obtained for pollen extracts from peat samples associated with the Mazama Ash layer are consistent with the range of bulk-sample dates obtained by others in previous studies. The limited measurement time and resulting precision $( \pm 100 \mathrm{yr})$ of these initial measurements restrict our ability to draw firm conclusions from a comparison of the pollen extract dates with previous bulk-sample dates. We intend to adjust our procedure to improve the rejection of non-pollen materials and to increase the precision of our ${ }^{14} \mathrm{C}$ measurements on pollen extracts from peat samples in future studies.

\section{INTRODUCTION}

The study of pollen preserved in lake sediment and peat deposits has proven to be one of the most important sources of information on continental paleoclimates. The fossil pollen in these deposits preserves a record of the local vegetation at the time of deposition into the lake sediment or peat. The variations in the plant types represented in the records and the past geographical distributions of these plant types have provided considerable information on the changes of continental vegetation and climate during the late Quaternary. One crucial component of palynological studies of lake sediment or peat deposits is the establishment of accurate and reliable chronologies for the pollen records. These chronologies provide the basis for correlating variations observed in cores from different sites and for relating the changes preserved in the pollen records to those found in other types of paleoclimatic records.

Radiocarbon dating is the predominant technique used in establishing independent chronologies for late Pleistocene and Holocene palynological records obtained from lake sediment or peat cores. Currently, the radiocarbon measurements are usually obtained by decay counting of the total organic carbon of bulk lake sediment or peat samples. The main reason for using the total organic carbon of bulk samples has been the sample size requirement of the decay-counting method (on the order of $1 \mathrm{~g}$ of carbon). Unfortunately, numerous studies have shown that there can be significant and varying differences between the radiocarbon content of the bulk sample total organic carbon and that of the proxy climate indicator actually being studied, e.g., pollen in palynological studies (Sutherland 1980; Andrée et al. 1986; Fowler, Gillespie \& Hedges 1986; MacDonald et al. 1987; Brown et al. 1989; Vogel et al. 1989; Williams 1989; Gillespie 1991; Tornqvist et al. 1992). The potential dating errors introduced by these differences can make the establishment of trustworthy chronologies difficult, and can introduce considerable unquantifiable uncertainty into studies of relatively short-lived paleoclimatic events, such as regional deglaciations, the Younger Dryas cooling and tree species migrations (e.g., Clayton \& Moran 1982; Brubaker, Garfinkel \& Edwards 1983; MacDonald et al. 1987; Peteet et al. 1990).

Accelerator mass spectrometry (AMS) has decreased the sample size required for ${ }^{14} \mathrm{C}$ measurements by three orders of magnitude to about $1 \mathrm{mg}$ carbon (or less). This allows sufficient carbon for measurement to be obtained using very selective sample preparation techniques that can isolate the

\footnotetext{
${ }^{1}$ Nuclear Physics Laboratory GL-10 and Department of Physics, University of Washington, Seattle, Washington 98195 USA

${ }^{2}$ Geophysics Program AK-50, University of Washington

${ }^{3}$ Quaternary Isotope Laboratory AK-60 and Department of Geological Sciences, University of Washington

${ }^{4}$ We regret the passing of our friend and colleague, Professor Emeritus Fred H. Schmidt, who died on January 17, 1991.
} 
material of interest from contaminants. We have used the ${ }^{14} \mathrm{C}$ AMS system at the University of Washington Nuclear Physics Laboratory to date directly pollen extracts from lake sediment and peat samples. This method allows the direct association of the obtained dates with the paleoclimatic indicator under study, and eliminates many of the potential sources of dating error that are inherent to bulk-sample dating. We present here preliminary results of our efforts to extend previous work in dating pollen extracts from lake sediments (Brown et al. 1989) to the extraction and dating of pollen from peat samples.

\section{METHODS}

The 5-cm-diameter core used in this study was taken from Kachess Bog near Cle Elum in Washington, USA $\left(47^{\circ} 16^{\prime} \mathrm{N}, 121^{\circ} 13^{\prime} \mathrm{W}\right)$ by T. Swanson, Quaternary Research Center, University of Washington. The site was formed as a lake impounded behind glacial maximum moraines sometime after $14 \mathrm{ka}$ BP. The site became a bog at about $8 \mathrm{ka}$ BP. Since that time, peat formation has been the only deposit, with the exception of two volcanic ash layers: 1) the Mazama Ash layer, which is about $10 \mathrm{~cm}$ thick and at a core depth of about $1.7 \mathrm{~m}$ (deposited about $6.6 \mathrm{ka} \mathrm{BP}$ ); and 2) an unidentified ash layer (possibly Mount Saint Helens Y) at a core depth of about $0.6 \mathrm{~m}$. There are no surface exposures of calcareous rock in the watershed of Kachess Bog (Swanson, personal communication 1991).

Core samples for pollen extraction and ${ }^{14} \mathrm{C}$ dating were taken from layers over- and underlying the Mazama Ash (designated KB-A and KB-B, respectively); Figure 1 shows the sampled core positions. At the depths from which the samples were taken, the core was composed of dense brown

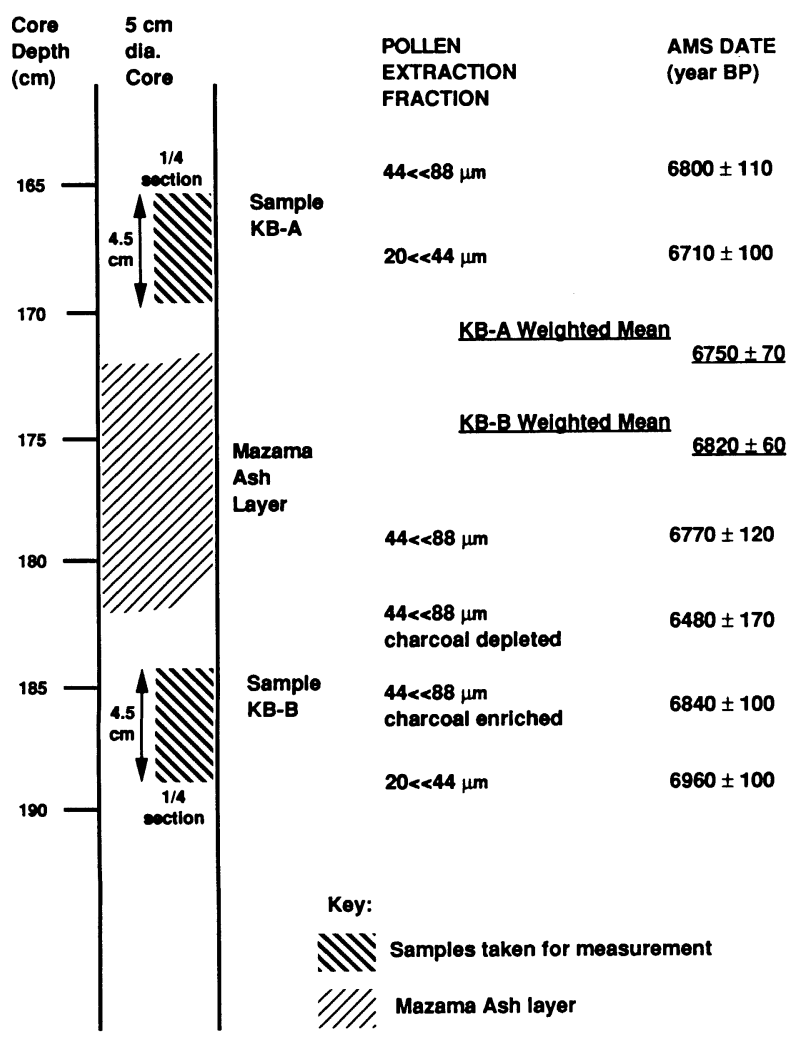

Fig 1. Dates obtained for pollen extracts from Kachess Bog peat samples. The profile at left shows the positions of the peat samples in this study from the 5-cm-diameter core relative to the Mazama Ash layer. The central column lists the pollen extract fractions for each sample; the righthand column gives the ${ }^{14} \mathrm{C}$ dates for the fractions. 
peat. Each of the samples was a $1 / 4$ cross-section core segment $4.5 \mathrm{~cm}$ long with a total volume of about $22 \mathrm{~cm}^{3}$. These large samples were taken to allow replicate processing of subsamples with variations of the pollen extraction procedure and were much larger than necessary to obtain sufficient pollen extract for dating.

Our pollen extraction procedure (Fig. 2) was a slightly modified version of the one used previously on lake sediment samples (Brown et al. 1989), and is similar to typical sample preparation methods used in palynological studies. The extraction procedure was designed to remove inorganic and nonpollen organic material from the extracts by exploiting the chemical inertness of the fossil pollen grains and by selecting the size fraction of the pollen. We anticipated considerably more difficulty in isolating pollen from the organic matrix of peat samples than was encountered in the case of lake sediments and altered the extraction procedure to improve the rejection of non-pollen contaminants. The changes we made to the lake sediment extraction procedure included:

1. Repeated treatment of the peat samples with $3 \mathrm{~N} \mathrm{KOH}$ solution in a boiling water bath to ensure removal of humic acids (as indicated by a colorless $\mathrm{KOH}$ solution after several $\mathrm{KOH}$ treatments)

2. $1 \mathrm{~N} \mathrm{HCl}$ treatment and $88 \mu \mathrm{m}$ sieving before the $29 \mathrm{~N} \mathrm{HF}$ (48\%, conc.)/boiling water bath step to decrease the size of the samples being treated with HF (while lake sediment samples we have prepared did not contain any $>88 \mu \mathrm{m}$ material, the $>88 \mu \mathrm{m}$ fraction of the peat samples was an order of magnitude larger than the $<88 \mu \mathrm{m}$ fraction)

3. Repeated treatment of the $<88 \mu \mathrm{m}$ and $<44 \mu \mathrm{m}$ fractions with $2-3 \% \mathrm{NaOCl}$ before sieving to improve the deflocculation and oxidation of the large amounts of amorphous debris found in these fractions from the peat samples.

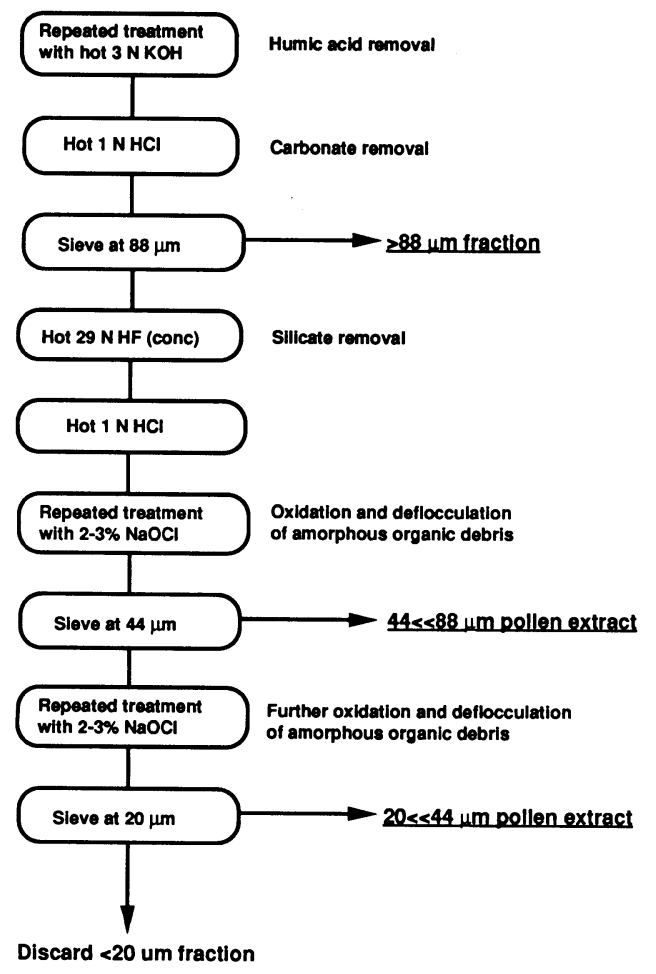

Fig 2. Outline of the method we used to extract pollen from peat samples. See text for discussion. 
One subsample of the HF-treated $<88 \mu \mathrm{m}$ fraction obtained from peat sample KB-A was prepared using the standard palynology acetolysis treatment (Faegri \& Iversen 1989) before sieving at 44 $\mu \mathrm{m}$ rather than the $2-3 \% \mathrm{NaOCl}$ treatment used in the pollen extraction procedure. This allowed comparison of the $44<<88 \mu \mathrm{m}$ product from the pollen extraction procedure with that obtained from the standard palynological sample preparation method.

One subsample of the $44<<88 \mu$ m pollen extract from peat sample KB-B was further separated into two fractions by centrifuging. The relatively rare charcoal fragments remaining in the pollen extract were concentrated into 1 of the 2 fractions. This fraction is referred to as " $44<<88 \mu$ m charcoal enriched" in Figure 1. The other fraction was essentially charcoal-free and is referred to as " $44<<88 \mu \mathrm{m}$ charcoal depleted" in Figure 1.

For the ${ }^{14} \mathrm{C}$ AMS measurements, pollen extract subsamples were dried at $c a .80^{\circ} \mathrm{C}$ overnight, sealed in evacuated Vycor tubes with $\mathrm{CuO}$ and then heated to $900^{\circ} \mathrm{C}$ for $1 \mathrm{~h}$ to oxidize the carbon in the pollen extracts to carbon dioxide. The carbon dioxide was converted to graphite by iron-catalyzed hydrogen reduction (Vogel et al. 1984) and prepared for our ion source as described previously (Balsley et al. 1987; Brown et al. 1990). The radiocarbon contents of the samples were then measured following the procedures described by Brown et al. (1990).

\section{RESULTS AND DISCUSSION}

Figure 3 shows photographs taken during microscopic examination of the extracts obtained from the peat samples.

The $>88 \mu \mathrm{m}$ fractions (Fig. 3A) were composed predominantly of plant fragments and other large debris. These fractions constituted the largest non-humic components of the peat samples, and their volume was an order of magnitude larger than that of the $<88 \mu \mathrm{m}$ fractions. The $>88 \mu \mathrm{m}$ fractions did not contain any recognizable pollen grains.

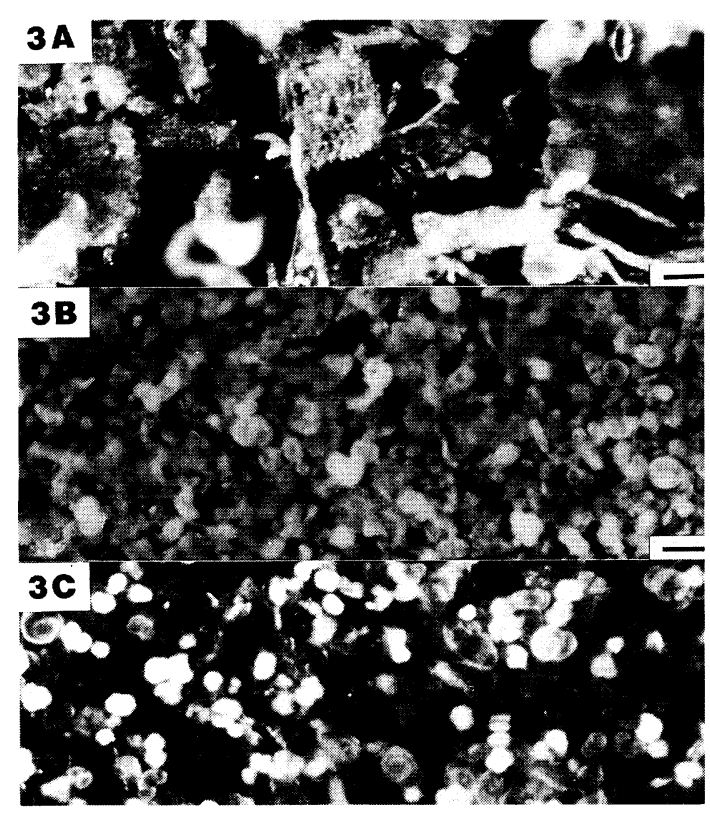

Fig 3. Photographs of three fractions obtained from the peat samples. The scale bars at the lower right of each photograph represent $c a .150 \mu \mathrm{m}$. A. The $>88 \mu \mathrm{m}$ fraction from sample KB-A showing the predominance of large plant fragments and other debris, and the absence of recognizable pollen in the $>88 \mu \mathrm{m}$ fractions. B. The acetolysis-treated $44<<88 \mu \mathrm{m}$ fraction from sample KB-A showing the predominance of clumps of amorphous debris and the presence of some recognizable pollen in such fractions. The fraction shown was prepared using a version of the standard palynological sample preparation method. C. The $44<<88 \mu$ m pollen extract from sample $\mathrm{KB}-\mathrm{A}$ showing the predominance of recognizable pollen and the small amounts of other materials in these extracts. We used our pollen extraction procedure shown in Figure 2. 
The acetolysis-treated $44<<88 \mu \mathrm{m}$ fraction (Fig. 3B) was composed predominantly of clumps of amorphous unidentifiable debris interspersed with some recognizable pollen grains; lake sediment samples that we have processed with this acetolysis treatment also contained similar clumps of amorphous debris. The acetolysis-treated $44<<88 \mu \mathrm{m}$ fraction clearly contained significant quantities of non-pollen material, and showed that the normal palynological sample preparation methods involving acetolysis are not sufficient to separate pollen from other components of the peat samples.

The $44<<88 \mu \mathrm{m}$ fractions (Fig. $3 \mathrm{C}$ ) produced by the pollen extraction were composed predominantly of clearly identifiable pollen grains, including Pinus, Picea, Pseudotsuga menziesii and Abies. These fractions also contained varying but generally small amounts of non-pollen material, including charcoal particles, occasional algae and unidentifiable cellulosic and waxy tissues. Comparison of the acetolysis- and $\mathrm{NaOCl}$-treated $44<<88 \mu \mathrm{m}$ fractions clearly shows the efficiency of the $\mathrm{NaOCl}$ treatments in deflocculating and oxidizing the amorphous debris to allow its separation from pollen during the sieving steps.

The $20<<44 \mu \mathrm{m}$ fractions produced by the pollen extraction procedure (not shown in Fig. 3 ) contained some relatively large identifiable pollen grains, but were composed predominantly of particles that were too small for identification under the magnification of the microscopes available at the time of these preliminary measurements. These smaller particles are probably a mixture of pollen grains from the various species that produce pollen in the $20<<44 \mu \mathrm{m}$ size range and smaller fragments of the cellulosic and waxy tissues also found in the $44<<88 \mu \mathrm{m}$ fractions. The $20<<44$ $\mu \mathrm{m}$ fractions also contained small amounts of charcoal particles.

Figure 1 shows the $\operatorname{six}{ }^{14} \mathrm{C}$ dates obtained for the pollen extracts from the peat samples along with weighted mean ages for the extracts from each peat sample. The dates were calculated following the conventions of Stuiver and Polach (1977), using an assumed $\delta^{13} \mathrm{C}$ value of $-29 \%$ o derived from previous measurements of pollen extract $\delta^{13} \mathrm{C}$ values (Brown et al. 1989). As these measurements were meant as initial tests of the procedure, the measurement time and precision were limited to obtaining a preliminary assessment of the effectiveness of the pollen extraction method. The date obtained for pollen extract, KB-B $44<<88 \mu \mathrm{m}$ charcoal-depleted, is somewhat younger than the other five dates we obtained; this could indicate contamination of the five samples by ${ }^{14} \mathrm{C}$ - "dead" coal particles. However, because of its relatively large uncertainty, the charcoal-depleted date is not inconsistent with the other dates and no firm conclusions can be drawn. The average of the five dates having approximately equal 1-o uncertainties of about $100 \mathrm{yr}$ is $6820 \mathrm{BP}$, and the standard deviation of their distribution is $90 \mathrm{yr}$; this indicates that the scatter of the dates agrees with the precision of the measurements. (The date for the KB-B $44<<88 \mu \mathrm{m}$ charcoal-depleted sample was excluded from this calculation because it is inappropriate to give this date, with its relatively large uncertainty, the same weight in calculations as the other five dates; the standard deviation calculation does not permit the variable weighting of data.)

The peat samples were taken from above and below the Mazama Ash, since this layer provided a convenient chronostratigraphic marker, and allowed comparison of our ${ }^{14} \mathrm{C}$ dates with the multitude of dates for the ash layer that had been obtained previously by others. The most commonly cited age for the Mazama ash layer of "about $6600 \mathrm{BP}$ " is derived from several ${ }^{14} \mathrm{C}$ dates from the earliest years of ${ }^{14} \mathrm{C}$ dating (Fryxell 1965). More recently published ${ }^{14} \mathrm{C}$ dates for the ash layer obtained from bulk peat and lake sediment samples, charcoal fragments and/or other organic matter associated with the ash layer are in the 6500-7000 BP range, with typical uncertainties of 100-200 yr (e.g., Clague 1980; Bacon 1983; Sarna-Wojcicki, Champion \& Davis 1983; Brown et 
al. 1989). Thus, the preliminary dates that we have obtained from the pollen extracts agree with the range of dates previously published for the Mazama Ash layer.

\section{CONCLUSIONS}

The preliminary results we have obtained on pollen extracts from peat samples are encouraging: microscopic examination of the products of the modified pollen extraction procedure used in this study shows that it is sufficient to remove almost all of the non-pollen materials from the extracts and to isolate an almost pure pollen fraction, and the ${ }^{14} \mathrm{C}$ dates obtained in this study are consistent with the range of dates obtained by others for the Mazama Ash. We intend to experiment further with several extraction variations to improve the rejection of non-pollen materials. While useful preliminary data were obtained, the limited measurement time and precision of these initial measurements were not sufficient for firm conclusions from comparison of these dates with the previous bulk-sample dates. We intend to increase the precision of our ${ }^{14} \mathrm{C}$ AMS measurements on pollen extracts from peat samples to allow more meaningful comparison of the pollen extract dates to bulk-sample dates.

\section{ACKNOWLEDGMENTS}

We thank the following from the University of Washington: Joseph A. Caggiano and Nancy Mar for their efforts in the development and utilization of the $0.7 \mathrm{~mm}$ sample Ta encapsulation technique; Travis Saling, Quaternary Isotope Laboratory, for graphitization of samples; Terry Swanson, Quaternary Research Center, for allowing us to subsample his Kachess Bog peat core; Minze Stuiver, Quaternary Isotope Laboratory, for advice and use of facilities; Melinda Denton, Botany, for access to and advice concerning the microscope used in obtaining Figure 3; the staff of the Nuclear Physics Laboratory (NPL) for their assistance and William Weitkamp, Technical Director, NPL, and Derek Storm, Director, NPL, for their encouragement and support.

\section{REFERENCES}

Andrée, M., Oeschger, H., Siegenthaler, U., Riesen, T., Moell, M., Ammann, B. and Tobolski, K. $1986{ }^{14} \mathrm{C}$ dating of plant macrofossils in lake sediment. In Stuiver, M. and Kra, R. S., eds., Proceedings of the 12th International ${ }^{14} \mathrm{C}$ Conference. Radiocarbon 28(2A): 411-416.

Bacon, C. R. 1983 Eruptive history of Mount Mazama and Crater Lake Caldera, Cascade Range, USA. Journal of Volcanology and Geothermal Research 18: 57-115.

Balsley, D. R., Farwell, G. W., Grootes, P. M. and Schmidt, F. H. 1987 Ion source sample preparation techniques for carbon-14 AMS measurements. In Gove, H. E., Litherland, A. E. and Elmore, D., eds., Proceedings of the 4th International Symposium on AMS. Nuclear Instruments and Methods B29: 37-40.

Brown, T. A., Farwell, G. W., Grootes, P. M., Quay, P. D. and Schmidt, F. H. $1990{ }^{14} \mathrm{C}$ AMS at the University of Washington: Measurements in a shared facility at the $1 \%$ level on $0.4 \mathrm{mg}$ samples. In Yiou, F. and Raisbeck, G. M., eds., Proceedings of the 5th International Conference on AMS. Nuclear Instruments and Methods B52: 351-356.

Brown, T. A., Nelson, D. E., Mathewes, R. W., Vogel,
J. S. and Southon, J. R. 1989 Radiocarbon dating of pollen by accelerator mass spectrometry. Quaternary Research 32: 205-212.

Brubaker, L. B., Garfinkel, H. L. and Edwards, M. E. 1983 A Late Wisconsin and Holocene vegetation history from the central Brooks Range: Implications for Alaskan palaeoecology. Quaternary Research 20: 194-214.

Clague, J. J. 1980 Late Quaternary geology and geochronology of British Columbia. Part 1: Radiocarbon dates. Geological Survey of Canada Paper 80-13.

Clayton, L. and Moran, S. R. 1982 Chronology of Late Wisconsinan glaciation in middle North America. Quaternary Science Reviews 1: 55-82.

Faegri, K. and Iversen, J. 1989 Textbook of Pollen Analysis, 4th edition. Chichester, John Wiley \& Sons: $328 \mathrm{p}$.

Fowler, A. J., Gillespie, R. and Hedges, R. E. M. 1986 Radiocarbon dating of sediments. In Stuiver, M. and $\mathrm{Kra}, \mathrm{R}$. S., eds., Proceedings of the 12th International ${ }^{14} \mathrm{C}$ Conference. Radiocarbon $28(2 \mathrm{~A}): 441-450$.

Fryxell, R. 1965 Mazama and Glacier Peak volcanic ash layers: Relative ages. Science 147: 1288-1290.

Gillespie, R. 1991 Charcoal dating-Oxidation is neces- 
sary for complete humic removal. Abstract. Radiocarbon 33(2): 199.

MacDonald, G. M., Beukens, R. P., Kieser, W. E. and Vitt, D. H. 1987 Comparative radiocarbon dating terrestrial plant macrofossils and aquatic moss from the "ice-free corridor" of western Canada. Geology 15: 837-840.

Peteet, D. M., Vogel, J. S., Nelson, D. E., Southon J. R., Nickmann, R. J. and Heusser, L. E. 1990 Younger Dryas climatic reversal in northeastern USA? AMS ages for an old problem. Quaternary Research 33: 219-230.

Sama-Wojcicki, A. M., Champion, D. E. and Davis, J. O. 1983 Holocene volcanism in the conterminous United States and the role of silicic volcanic ash layers in correlation of latest-Pleistocene and Holocene deposits. In Wright, H. E., Jr, ed., Late Quaternary Environments on the United States, Vol. 2. Minneapolis, University of Minnesota Press: 52-77.

Stuiver, M. and Polach, H. A. 1977 Discussion: Reporting of ${ }^{14} \mathrm{C}$ Data. Radiocarbon 19(3): 355-363.

Sutherland, D. G. 1980 Problems of radiocarbon dating deposits from newly deglaciated terrain: Examples from the Scottish Late Glacial. In Lowe, J. J., Gray,
J. M. and Robinson, J. E., eds., Studies in the LateGlacial of North-West Europe. Oxford, Pergamon Press: 139-149.

Tornqvist, T. E., de Jong, A. F. M., Oosterbaan, W. A. and van der Borg, K. 1992 Accurate dating of organic deposits by AMS ${ }^{14} \mathrm{C}$ measurements of macrofossils. Radiocarbon, this issue.

Vogel, J. S., Briskin, M., Nelson, D. E. and Southon J. R. 1989 Ultra-small carbon samples and the dating of sediments. In Long, A. and Kra, R. S., eds., Proceedings of the 13th International ${ }^{14} \mathrm{C}$ Conference. Radiocarbon 31(3): 601-609.

Vogel, J. S., Southon, J. R., Nelson, D. E. and Brown, T. A. 1984 Performance of catalytically condensed carbon for use in accelerator mass spectrometry. In Wölfli, W., Polach, H. A. and Andersen, H. H., eds., Proceedings of the 3rd International Symposium on AMS. Nuclear Instruments and Methods B5: 289293.

Williams, J. B. 1989 Examination of freshwater peat pretreatment methodology. In Long, A. and Kra, R. S., eds., Proceedings of the 13th International ${ }^{14} \mathrm{C}$ Conference. Radiocarbon 31(3): 269-275. 